\title{
DESIGN AND DEVELOPMENT OF MOBILE MILK CHILLER
}

\author{
Abrarahmad S. Mulla \\ Department of Mechanical Design Engineering, \\ RIT, Islampur, Maharashtra, India
}

\begin{abstract}
Bulk milk chiller is system that is used to cool milk up to $3-4^{\circ} \mathrm{C}$ from $35^{\circ} \mathrm{C}$ to reduce the growth of microorganisms and to maintain its quality as per international standards. Bulk-milk chiller consists of three major parts : milk cooling tank, refrigeration and milk release pump. Cooling media which is cooled by refrigeration system utilize to maintain the milk temperature in required range to avoid milk spoilage. The work deals with design and develop effective and economical BMC to achieve required temperature with minimum time by consideration of factors like, cop, optimization, energy consumption of components . also system analysis.
\end{abstract}

Keywords-Refrigeration system, cop, chilling time, energy consumption, Analysis

\section{INTRODUCTION}

Supply of crude milk as of town to dairy require part of care because no cooling unit available at rural gathering focus. To look after quality, the milk must be chilled at town level. as the amount of milk gathered lesser amount of 40 - 200 ltr cooling doesn't happen at this level mass milk chillers are not sensible. The temperature of milk at the hour of draining is about $37^{\circ} \mathrm{C}$. It is to be quickly chilled to $4^{\circ} \mathrm{c}$ to check the advancement of scaled down living things and to keep up its quality as indicated by worldwide standards. hence it is required to chill the milk while transport and directly use for secondary process. "A. Mohamed et. al. (2007).[1] studied milk temperature was expanded by 3.43 and $144 \%$ for both each and every other day milk gathering tests progressively. Then again during the primary milk stacking milk temperature was decreased by 4.72 and $546 \%$ for both each and every other day milk gathering tests separately. "

"V. Hegde et. al. (2014).[2] have investigated that milk should be chilled to $10{ }^{\circ} \mathrm{C}$ inside four hours or less in any case bacterial development expands subsequently cutting down the milk quality. Most appropriate refrigeration framework is mechanical refrigeration framework for Indian conditions. The significant favorable position of this undertaking is that the milk chilled in the van can be utilized for optional preparing if bundling unit is found even at $4-5 \mathrm{hr}$ excursion time. Chilling plant isn't vital which can be supplanted by portable chillers."

\author{
Dr. Ramchandra G. Desavale \\ Department of Mechanical Design Engineering, \\ RIT, Islampur, Maharashtra, India
}

"D. Ghewade et. al. (2007).[3] have predicted that exploratory estimations of execution boundaries, for example, work input, coefficient of execution, and condenser refrigerant temperature intently coordinate with one another. Yet, it actually required improving these models to give more precise outcomes with less number of sources of info. Point by point model of evaporator utilizing explicit or more precise warmth move connection for channel math is needed to be created to precisely anticipate the evaporator refrigerant temperatures and regions of single stage and two stage stream."

" Indian Mirror, Indian dairy at glance.(2012).[4] have describes dairy segment part in the nation's financial turn of events and adds to the significant section of provincial economy. dairying has become a noteworthy discretionary wellspring of compensation for some commonplace families. It not just assumes a significant part in giving business and pay producing openings close to farming, yet additionally guarantees gracefully of value milk and Milk things to both metropolitan and rural locales with the country's extending enthusiasm for milk and milk things, the dairy business is likewise developing quickly. As indicated by "Indian Dairy Industry Analysis", India is the world's greatest milk maker representing around $17 \%$ of the worldwide milk creation."

"Chandy K. T, et al.(2014)[5] studied requirements of Milk to be chilled to $10{ }^{\circ} \mathrm{C}$ inside four hours or less in any case bacterial development builds in this manner cutting down the milk quality. Most appropriate refrigeration framework is mechanical refrigeration framework for Indian conditions. Information gathered from town co-usable social orders was taken for plan. Idea was planned remembering ergonomics and furthermore lessening the exertion and time for stacking and emptying the milk jars to the vehicle. The significant favorable position of this venture is that the milk chilled in the van can be utilized for auxiliary preparing if bundling unit is found even at $4-5 \mathrm{hr}$ excursion time. Chilling plant isn't fundamental which can be supplanted by portable chillers."

"J. "Garvin (2010) [6]. Describe the relation to find frictional pressure drop in dimple jacket and also derived the relation to find overall heat transfer coefficient to design of dimple jacket which will help to design the dimple jacket . He also descirbe that dimple jacket is more efficient than other ways of heat exchanger for better performance and improvement due to turbulence generated by dimples." 


\section{International Journal of Engineering Applied Sciences and Technology, 2020 \\ Vol. 5, Issue 6, ISSN No. 2455-2143, Pages 288-291 \\ Published Online October 2020 in IJEAST (http://www.ijeast.com)}

\section{DESIGN OF CHILLING UNIT}

Internal pressure calculation carried out in storage tank design to decide the bare minimum thickness of storage tank under inner pressure UG 27-thickness of storage under inside tension and ug 32 shaped heads pressure on curved side from ASME Section VIII Div.1used for external pressure calculation. By considering the internal pressure calculation minimum thickness came to $4 \mathrm{~mm}$ for tank and $8 \mathrm{~mm}$ for torispherical head. In external pressure calculation, maximum allowable external pressure will be calculated for thickness calculated in internal pressure calculation. This maximum allowable external pressure must be greater than the design external pressure. . Ug 28 thickness of capacity tank under outer tension and ug 33 shaped heads pressure on arched side from asme segment viii div 1 used for the external pressure calculation. Value of factor A acquire from the ASME section II part D Metric. After calculations thickness of all components of storage tank is greater than design external pressure. Hence we conclude that our design is safe theoretically .

Further calculation is done for refrigeration system under reference of ASHRAE. The system is designed to carried out heat from milk storage tank which is came to 4 TR . Designed dimple jacket as a heat exchanger for removal of heat from storage. cooling media used for the system is having water + Ethylene glycol $(w+20 \% \mathrm{E})$. Designed dimple jacket is having more proficiency due to higher overall heat transfer coefficient. Those designed a system which having lowest capacity and high performance and reduce the time of cooling as well.

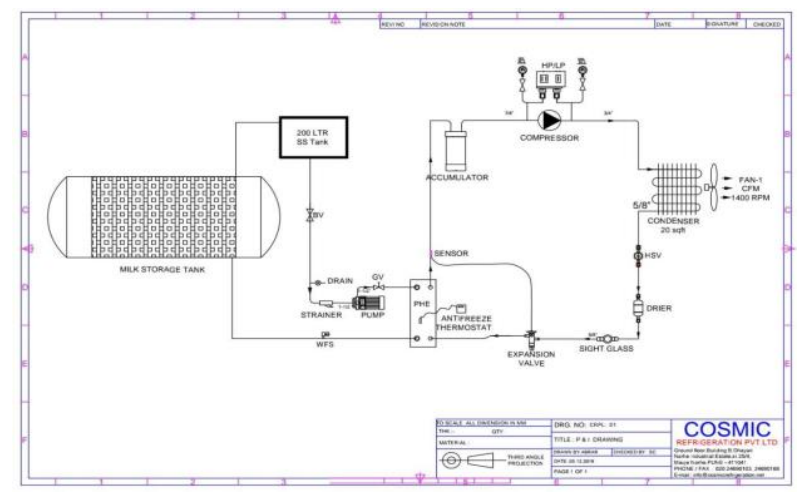

Fig, 1. Piping \& InStRUmentation Diagram

The fig 1 shows the arrangement of parts of refrigeration and mechanical system . Fig 2shows the general arrangement diagram which includes the all setup of the tank with accessories and fittings, refrigeration system, milking system and other control panel. This set up is then fitted in the skid which is completely covering the bulk milk chiller assembly.

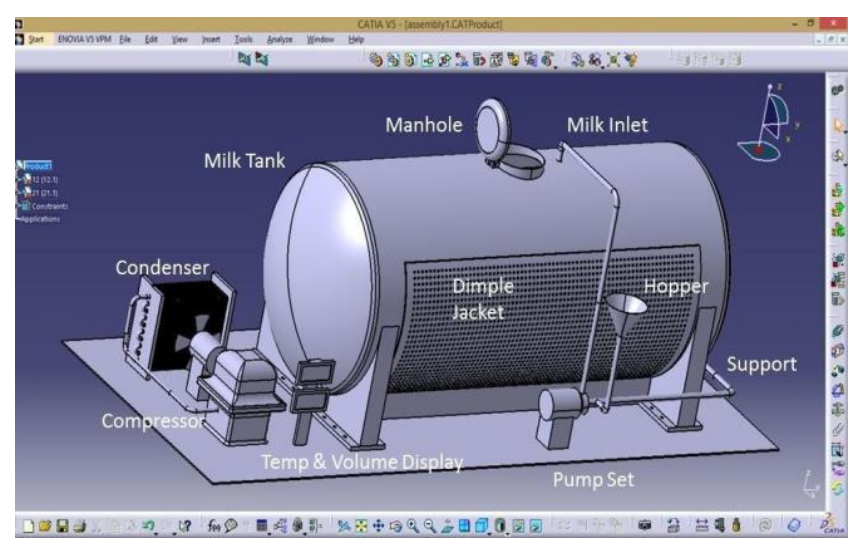

Fig 2.General Arrangement Diagram of Milk chiller Table1 : Component specification

\begin{tabular}{|c|c|}
\hline Components & Specification \\
\hline Bulk Milk Chiller Capacity & 1000 ltr \\
\hline Milk Tank & 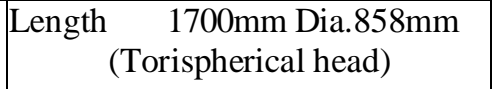 \\
\hline Temperature Range & $35^{0} \mathrm{C}-1^{0} \mathrm{C}$ \\
\hline HP LP & Danfoss make \\
\hline S.S. Milk Pump & $1 \mathrm{HP}$ \\
\hline Milk Hopper & Standard Size available \\
\hline Compressor & $\begin{array}{l}\text { 14.595kw capacity } \\
\text { (4 Tonnes) } \\
\text { Hermetically sealed } \\
\text { scroll compressor }\end{array}$ \\
\hline Condenser & $\begin{array}{c}\text { Air cooled condenser with copper } \\
\text { tubing } \\
\text { (ISO 5708 Type 2A II) latest } \\
\text { version,84.639 Sqft with 3/8" tube }\end{array}$ \\
\hline Evaporator & Jacketed Type Evaporator \\
\hline Refrigerant & R404A (Quantity- 4kg) \\
\hline Temperature Sensor & $\begin{array}{l}\text { RL5 Controller with accuracy } \\
0.1^{0} \mathrm{C} \\
\end{array}$ \\
\hline
\end{tabular}




\section{International Journal of Engineering Applied Sciences and Technology, 2020 \\ Vol. 5, Issue 6, ISSN No. 2455-2143, Pages 288-291 \\ Published Online October 2020 in IJEAST (http://www.ijeast.com)}

\section{STRCTURAL ANALYSIS}

Modeling of system is done by sing solid work software and further converted to XT file for analysis purpose. The cad model of system is as shown in figure 3 .

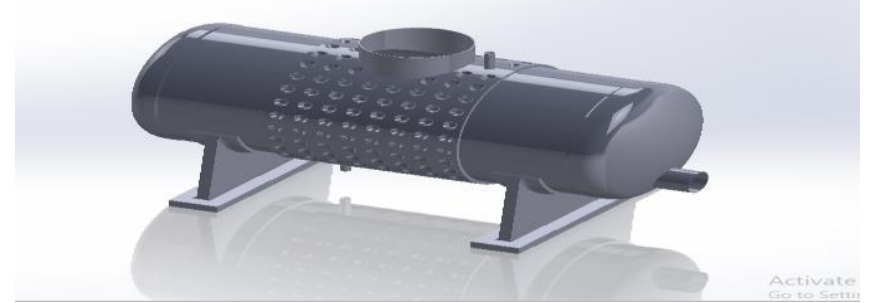

Fig 3.CAD Model of Milk chiller

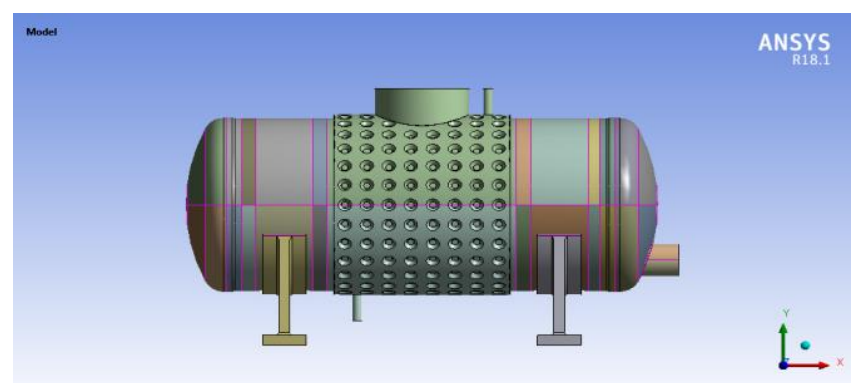

Fig 4.Slicing of whole system

Fig 4. shows the slicing of unit to provide path for meshing .we required minimum number of node and elements for which the slicing is best option.

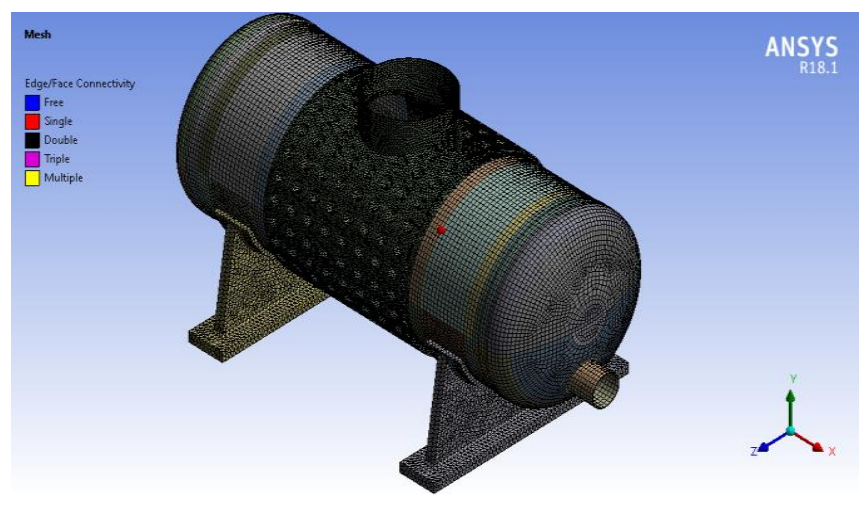

Fig 5. Meshing

Meshing is done after slicing of whole system which will provide path for meshing de to which the element on vessel are Hex element and on jacket it is having Tet element overall count of nodes and element are reduces. Fig 5. shows the meshing of whole system and fig 6 . indicate the hex mesh on

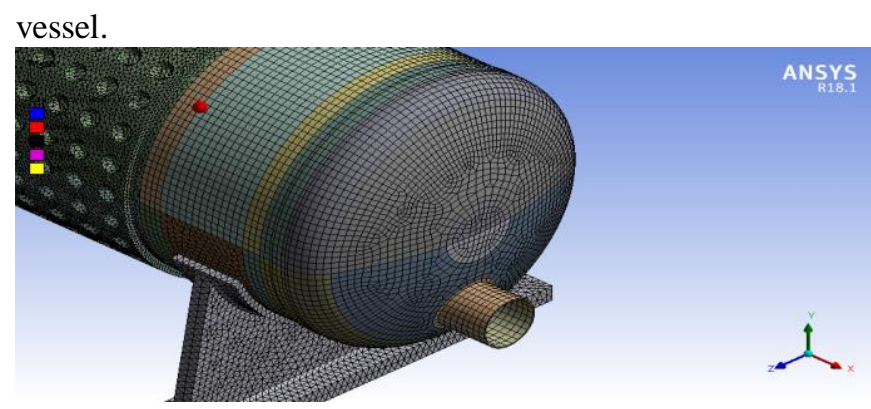

Fig 6 .Hex mesh on vessel

Afterwords the gravity and covection loading conditions are given to the system as shown in figure 7 and figure 8 respectively. total no. of nodes are 637662 and elements are 315102.

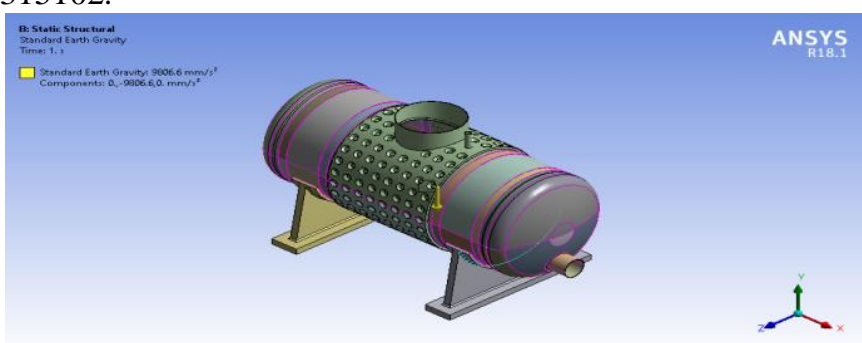

Fig 7 .Gravity loading condition

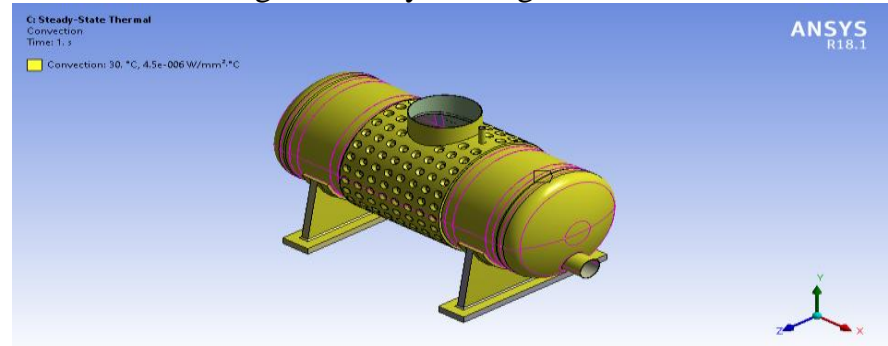

Fig 8 .convection loading condition System movement restricted by providing fixed support at saddle bottom .as shown in fig 9 .

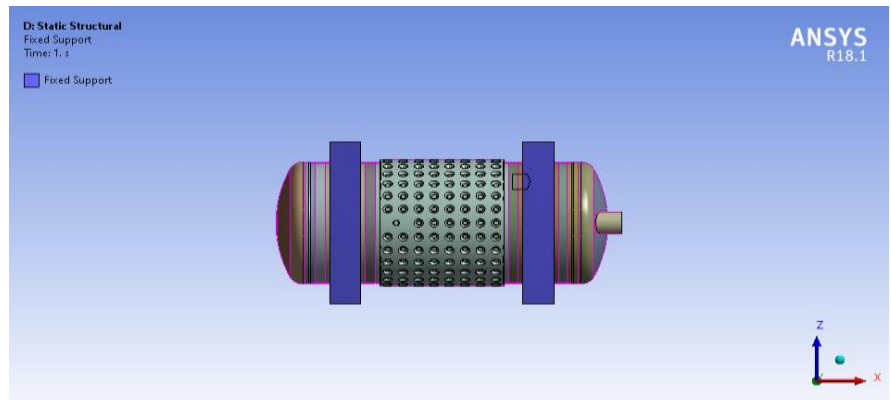

Fig 9. Fixed support

Pressure loading conditions and temperature loading condition are provided at both jacket and vessel side . Thrust loading 


\section{International Journal of Engineering Applied Sciences and Technology, 2020 \\ Vol. 5, Issue 6, ISSN No. 2455-2143, Pages 288-291 \\ Published Online October 2020 in IJEAST (http://www.ijeast.com)}

conditions are provided at manhole. Also thrust loading conditions are given at jacket inlet and outlet.

\section{RESULTS}

After providing all loading conditions the analysis is run and we find total deformation and equivalent stress as shown in figure10 and figure 11 respectively .

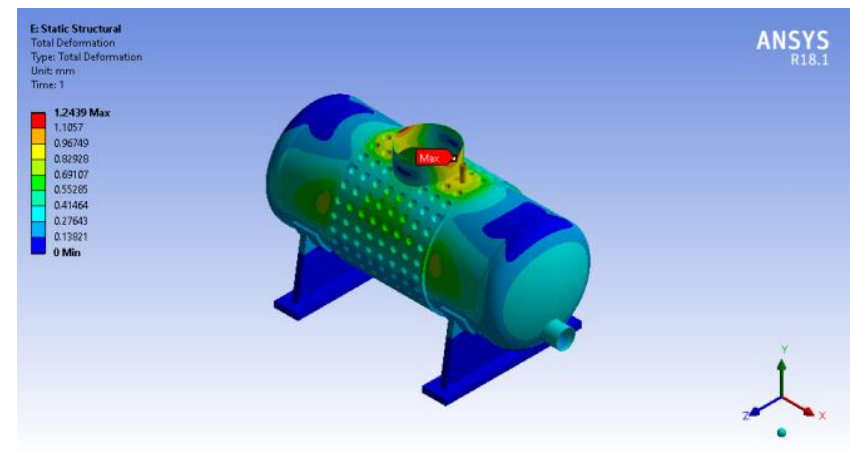

Fig 10 .Resultant total deformation

By analysis we found that deformation is $1.2439 \mathrm{~mm}$ maximum at jacket inlet and which is not affected more to or system .

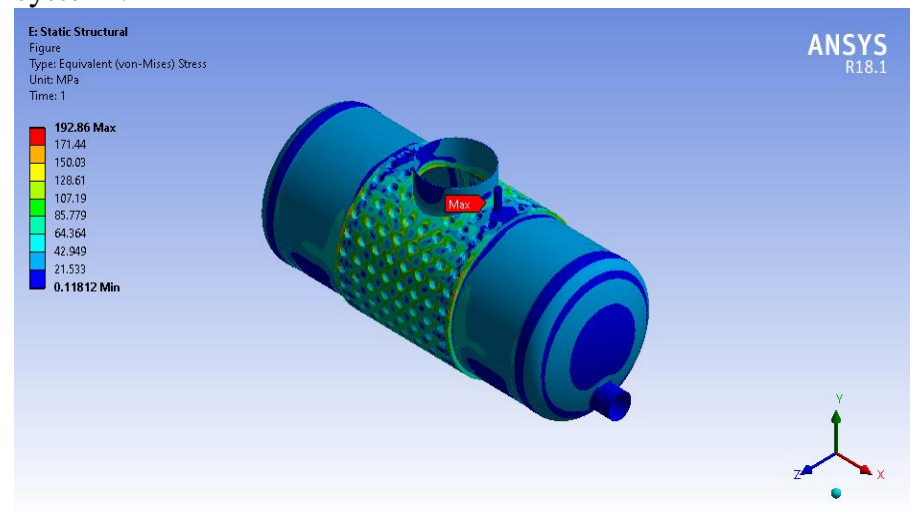

Fig 11 .Resultant Equivalent stress

By doing stress analysis we found that 192.82 Mpa which is less than yield strength of the material used for the design of pressure vessel SS304.

\section{CONCLUSION}

By utilizing mobile bulk milk chiller the milk can be chilled during transport itself. By doing analysis we found that designed system is safe for the condition in which it is operated. It is found that equivalent stress value is fond less than that of yield strength so or calculation for system is found correct. It is observed that manufactured system is capable to sustain loads and having strength to stand with actual load conditions.

\section{REFERENCE}

[1] Basiony A., and Abdallah, S., (2007). "Evaluating the Performance Of A Bulk-Milk Cooler On A Dairy Farm" Eng., 24(4): 956- 977 , (pp. 976).

[2] Hegde V., Bhattachrya A., and Srikari S., (2014). "Design Of Mobile Raw Milk Chilling Unit For Rural Areas" SASTECH Journal; Volume 13; Issue 1, (pp. 34).

[3] Ghewade D., Sapali S., and Kajale S., (2007). "Dynamic Modeling of Bulk Milk Cooler"5th International Conference on Heat Transfer, Fluid Mechanics and Thermodynamics Sun City, South Africa.

[4] Agrawal A., Dave, R., and Shrivastava, K., (2002). " Design Modifications In Compressor Of Milk Chilling Unit For Eco- Friendly Refrigerants "International Compressor Engineering Conference Paper( 1530)

[5] Elena A; (2009). "Analysis Of Milk Quality And Its Importance For Milk Processors"; (pp,506)

[6] Umoru L, Afonja A., and Ademodi B;(2008) "Study of AISI 304, AISI 321 and AISI 430 Stainless Steels"; Journal of Minerals \& Materials Characterization \& Engineering; 2008,( pp. 291-299).

[7] Tipole P., Patil A., Ponathil A., Oak N., Salvekar Pinak;(2015) "System Design and Experimental Results ofProgressive Freeze Concentration System"; International Journal of Application or Innovation in Engineering \& Management; (Volume 4, Issue 7)

[8] Kulkarni A, Patil K,Petkar M , Patil P; (2014) "Investigation of Heat Transfer Co-Efficient In SemiElliptical Horizontal Bulk Milk Cooler"; (Vol. 2, Issue II, ; pp. 51)

[9] Tassou S., De-Lille G., Lewis J.;(2012) "Food transport refrigeration";http://www.grimsby.ac.uk/documents/defra /trns-refrigeenergy.pdf, (Retrieved on 13th)

[10] Indian Mirror, Indian dairy at glance, http://www.indianmirror.com/indianindustries/2012/dairy- 2012.html, retrieved on 10th Dec. 2012. 